\title{
Do Freight Rates for Produce and Ornamentals Cover Costs?1
}

Richard Beilock ${ }^{2}$

\section{Introduction}

Over $99 \%$ of Florida's interstate produce and ornamentals shipments are by truck. As such, it is important to Florida agriculture that these carriers be financially viable. At the same time, shipper/receivers are interested in paying the least cost possible for haulage. They are also interested in having reliable motor carrier service, which is only possible if freight rates are sufficient to cover costs. In this report, the adequacy of freight rates paid for produce and ornamentals movements out of Florida and freight rates received for complementary haulage into the state will be examined. Data come from a 2001/2002 survey of over 1,600 drivers of semis as they exited the Florida Peninsula (Appendix; Beilock, 2004).

\section{Total Revenues}

The average driver hauling a load of produce or ornamentals from Florida during the 2001/2002 shipping season reported a freight rate of $\$ 1,909$. When combined with freight rates reported for the load (if any) hauled into Florida (averaging \$1,649), round-trip revenues averaged $\$ 3,558$. On a per-mile basis, freight rates averaged:
- \$1.63 per mile for produce/ornamentals outbound from Florida.

- \$1.96 per mile for produce/ornamentals inbound to Florida.

- $\$ 1.72$ per mile for produce/ornamentals round-trip.

It should be noted that the somewhat lower per-mile freight rate for the outbound movement was due to the longer average-trip distance for outbound versus inbound loadings (1,246 and 939 miles, respectively).

\section{Determining Sufficient Earnings}

It is important to know whether earnings are sufficient to cover carrier costs. Until 1996, the United States Department of Agriculture (USDA) calculated and published operating costs for inter-city produce haulers (Buxton and Bertels, 1993). In that year, the estimated per-mile cost was $\$ 1.34$. Using the Consumer Price Index, or the Producer Price Index for Trucking and Courier Services, Except Air, this would be equivalent to $\$ 1.54$ or $\$ 1.58$ per mile, respectively, in terms of 2002 U.S. dollars. With regard to round-trip movements as well as both the

1. This is EDIS document, FE541, a publication of the Department of Food and Resource Economics, Florida Cooperative Extension Service, Institute of Food and Agricultural Sciences, University of Florida, Gainesville, FL. Published March 2005. Please visit the EDIS website at http://edis.ifas.ufl.edu.

2. Richard Beilock, Professor, Department of Food and Resource Economics, Florida Cooperative Extension Service, Institute of Food and Agricultural Sciences, University of Florida, Gainesville, FL.

The Institute of Food and Agricultural Sciences is an equal opportunity/affirmative action employer authorized to provide research, educational information and other services only to individuals and institutions that function without regard to race, color, sex, age, handicap, or national origin. For information on obtaining other extension publications, contact your county Cooperative Extension Service office. Florida Cooperative Extension Service/Institute of Food and Agricultural Sciences/University of Florida/Christine Taylor Waddill, Dean. 
outbound and inbound portions of the journey, per-mile revenues exceed these cost estimates, so, at face value, earnings appear to be sufficient.

Whether in fact earnings are sufficient also depends upon the amount of empty mileage. Because the inbound average freight rate estimates given above already include empty inbound movements, it is necessary to calculate cost per mile for all miles driven. The USDA's estimates assumed full return trips toward the produce production area three-quarters of the time. In other words, for every 100 miles a carrier hauls produce away from a production area, to be revenue adequate, the carrier had to collect revenues sufficient for that particular 100 miles plus an additional 25 miles. Since the $\$ 1.58$ per-mile estimate includes this allowance for empty mileage, the actual cost per mile, both empty and full, would be $\$ 1.26$ [(100/125) x $\$ 1.58=\$ 1.26]$. Using this estimate again, produce hauler revenues appear to be more than adequate, at least with respect to transport into and out of Florida.

Before concluding that revenues are adequate, repositioning costs should be considered. As noted previously, the average inbound haul was shorter than the average outbound haul. This can be due to one of three reasons:

\section{The inbound and outbound movements were not} the two legs of a round trip, but simply two segments of a many-segmented, widely wandering trip. There would be no expected impacts on the revenue adequacy estimates of this type of operation. It is difficult to judge the extent to which this occurs, though it seems likely that produce haulers would tend to cycle back and forth between a currently active production area and destinations for its product. That this is the case is suggested by the following example. Of the drivers in the sample heading to New York with produce/ornamentals at the time of the survey, 58\% had just brought a load to or traveled empty from New York or a bordering state, and $28 \%$ picked up inbound products from a state located between New York and Florida. So this operational approach would not affect the revenue adequacy estimates.
2. The carrier hauled cargoes partway towards Florida and traveled the rest of the way to the State empty. To the extent this occurred, the revenues earned for partway to Florida were not recorded in the survey. So total inbound and round-trip revenues were understated and, though probably to a lesser degree, the corresponding per-mile revenue estimates were understated.

\section{The carrier traveled empty partway to Florida} before picking up its loading for the journey into the State. To the extent this occurred, total inbound and round-trip revenues would have still been correct, but the corresponding per-mile revenue estimates were overstated because the mileage repositioning to secure the load was not accounted for.

Actually (almost surely), average inbound distances were shorter than average outbound distances largely because of instances of both \#2 and \#3 above. A lower-bound estimate for revenue per mile could be made by assuming that the inbound/outbound distance differential is entirely due to \#3 (in every instance in which inbound distances appear shorter than outbound distances, it is because carriers must first travel empty toward Florida to then bring a load into the State). Using this very conservative assumption, the same total freight rate amounts would be used, but the averages of both the inbound and outbound movements would be 1,246 miles. The resulting per-mile revenues averaged $\$ 1.63$ per-mile freight rate for produce/ornamentals outbound from Florida, \$1.32 for produce/ornamentals inbound to Florida, and \$1.43 for produce/ornamentals round-trip.

Even with this very conservative assumption which, almost surely, understates per-mile revenues, for each leg of the round-trip, as well as over the round-trip itself, per-mile revenues exceed the $\$ 1.26$ estimate derived from the USDA methodology. Therefore, it can be concluded that, for truckers serving the Florida produce and ornamentals industry in 2001/2002, revenues were adequate. 


\section{Summary}

Based on a large survey of drivers during the 2001/2002 shipping season and updated operating costs developed by the USDA, the freight rates that produce and ornamentals carriers receive appear sufficient to cover their costs. Since Florida's agriculture depends upon a viable trucking industry, this is good news. It should be stressed, however, that the findings constitute a picture of the situation during only one shipping season. As input costs change, particularly labor and fuel, net returns to trucking may vary over time.

\section{References}

Beilock, R. 2004. Long Distance Refrigerated Trucking: A Florida Case Study. Report prepared for the Agricultural Marketing Service, United States Department of Agriculture, Washington, D.C.

Beilock, R., J. MacDonald, and N. Powers. 1998. An Analysis of Produce Transportation: A Florida Case Study. ERS/USDA Agricultural Economic Report 597, Washington, D.C., 43 pp.

Buxton, F., and P. Bertels. 1993. Estimating Refrigerated Motor Carrier Cost: A Methodology Using Secondary Data. Journal of the Transportation Research Forum 33 (2):26-32.

Household Goods Carriers Bureau. 1985. Household Goods Carriers Bureau Mileage Guide No. 13. Household Goods Carriers Bureau, Alexandria VA.

\section{Appendix: Data}

The 2001/2002 Driver Survey: This survey was conducted in November of 2001, and in January, March, and May of 2002. The survey sites included the Florida Agricultural Inspection Stations located on interstate highways U.S. I-10, U.S. I-75, and U.S. I-95. The drivers of 1,642 refrigerated tractor-trailers were interviewed as they exited the Florida Peninsula.

While the survey sites were all in Florida, the study has relevance for long-distance haulage throughout North America. The sample contained drivers from all 48 contiguous U.S. states and 8
Canadian provinces. These drivers were enroute to destinations in 46 states, the District of Columbia, and 7 Canadian provinces. Trip distances ranged from 100 to 3,347 miles, averaging 1,222 miles. 